\title{
Campesinato e agricultura familiar em duas imagens: o sem-terra raivoso e a família feliz ${ }^{1}$
}

\author{
Peasantry and family farming in two pictures: the angry landless and the happy \\ family \\ Campesinado y agricultura familiar en dos imágenes: el sin tierra enojado y la \\ família feliz
}

Patrícia da Veiga Borges ${ }^{2}$

http://dx.doi.org/10.5216/35015

\section{Resumo}

Este trabalho discute qual natureza de representação podem ter o campesinato e a agricultura familiar, considerando como foco principal de análise o uso das emoções na formulação de enunciados midiáticos. Toma como pontos de análise duas imagens: uma fotografia apresentada como capa da Revista Veja, em 1998, e um desenho de 2014, estampado no selo promocional do Ano Internacional da Agricultura Familiar (AIAF). Como parte da reflexão teórica, faz uma associação entre os termos "campesinato" e "agricultura familiar" e discute a relação entre comunicação, emoções e poder. À guisa de conclusão, defende que os retratos do campo poderiam tornar explícitas as contradições da questão agrária brasileira.

Palavras-chave:Agricultura Familiar. Campesinato. Emoções. Representação.

\begin{abstract}
This paper discusses nature of representation which can have the peasantry and the family farm, considering as main focus the use of emotions in the formulation of media statements. Takes as points of analysis two images: a photograph presented in a cover of Veja magazine, in 1998, and a drawing of 2014, stamped on the promotional seal of the International Year of Family Farming (AIAF). As part of theoretical reflection, makes an association between the terms "peasantry" and "family farm" and discusses the relationship between communication, emotions and power. In conclusion, argues that the portraits of the countryside can make explicit the contradictions that permeate brazilian agrarian question.
\end{abstract}

Keywords:Emotions. Family Farming. Peasantry. Representation.

\section{Resumen}

En este trabajo se discute que representaciones pueden tener el campesinado y la agricultura familiar, teniendo en cuenta el uso de las emociones en la composición de los enunciados midiáticos. Toma como punto de análisis dos imágenes: una fotografía presentada por Revista Veja en 1998 y un dibujo de 2014, el sello de promoción del Año Internacional de la Agricultura Familiar (AIAF). Como parte de la reflexión teórica, hace una relación entre los términos "campesinado" y "agricultura familiar" y

\footnotetext{
${ }^{1}$ Este texto foi elaborado com base nas contribuições da disciplina Comunicação e Sociedade - Comunicação, Emoçães e Poder, ministrada pelo prof. Dr. João Freire Filho no âmbito do Programa de Pós-Graduação em Comunicação da Universidade Federal do Rio de Janeiro (ECO-POS/UFRJ), entre os meses de fevereiro e junho de 2014.

${ }^{2}$ Doutoranda do Programa de Pós-Graduação em Comunicação da Universidade Federal do Rio de Janeiro (ECO-POS/UFRJ), Mestra em Comunicação pela Universidade Federal de Goiás (UFG), vinculada à linha de pesquisa Mídia e Mediações Socioculturais e integrante do Laboratório de Estudos em Comunicação Comunitária (LECC/UFRJ). Brasil, Rio de Janeiro (RJ), Rio de Janeiro.E-mail: patriciadaveiga@gmail.com
}

Comun. \& Inf., Goiânia, GO, v. 18, n. 1, p. 157-173, jan./jun. 2015

Caderno Casadinho Procad UFG - UFRJ 
se analiza la relación entre la comunicación, las emociones y el poder. En conclusión, se defende que las representaciones del campo expliciten las contradicciones de la cuestión agraria brasileña.

Palabras clave: Agricultura Familiar. Campesinado. Emociones. Representación.

\section{INTRODUÇÃO}

O inimigo desairado revivesceu com vigor incrível. Os combatentes, que o enfrentavam desde o começo, desconheceram-no. Haviam-no visto, até aquele dia, astucioso, negaceando na maranha das tocaias, indomável na repulsa às mais valentes cargas, sem par na fugacidade com que se subtraía aos mais improvisos ataques. Começaram a vê-lo heróico. (EUCLIDES DA CUNHA, Os sertões ${ }^{3}$ ).

Blaudes, ao presenciar o modo como aqueles homens chegaram, gerando insegurança, muito nervoso, conteve a vontade de dar uma gargalhada. Cerrou nos lábios o sorriso numa contração muscular, sério, sufocando-o num silêncio absoluto, quase em estado de pânico. Observava igualmente naqueles homens de farda um olhar de terror, o que o fez concluir que, fosse o que fosse acontecer, era chegada a hora. Esses homens seguravam suas armas como se elas estivessem para cair, firmando o dedo no gatilho, transmitindo pavor. Apesar de estarem fortemente armados, pareciam temer o silêncio dos moradores, que tinham nas mãos seus instrumentos de trabalho - do facão à foice. Talvez o que mais receavam fosse a estratégia de um povo que já não tinha muito a escolher: se viveria como eterno perdedor ou se morreria como herói.(BLAUDES SOUZA, Japuara $^{4}$ ).

Como bem ilustram os excertos acima, o campo, no Brasil,não é terreno neutro. Pelo contrário, é chão de muitos e terra para poucos. É o contexto e o espaço onde o capitalismo pôde se organizar, ao final do século XIX, alicerçado na concentração fundiária e amparado pelo Estado que se formava (OLIVEIRA, 2001; IANNI, 2004). É onde, ainda na atualidade, formasprecárias de trabalho, tais como a peonagem e a escravidão por dívida, sobrevivem juntamente coma produção agrícola mecanizada (MARTINS, 2013). O confronto e a violência são elementos marcantes na trajetória do campesinato brasileiro: de Canudos (BA) a Canindé (CE), do Império à República, de Euclides da Cunha a Blaudes Souza. A vida dos expropriados da terra está em frequente disputa com o valor do hectare e dos recursos naturais.

\footnotetext{
${ }^{3}$ CUNHA, Euclides da. Os sertões: (Campanha de Canudos). Rio de Janeiro: Ediouro, 1998. 20a . Ed. O trecho aqui recortado encontra-se no capítulo 10, página 470 .

${ }^{4}$ Memórias escritas pelo trabalhador Francisco Blaudes Souza Barros sobre a "chacina de Japuara", confronto entre lavradores, policiais e jagunços ocorrido em 2 de janeiro de 1971 na Fazenda Japuara, localizada no sertão de Canindé (CE). Na ocasião, a terra estava sob litígio, sendo disputada por famílias que ali viviam desde a década de 1950 e pelo fazendeiro e comerciante da região Júlio César Campos. O texto da epígrafe pode ser localizado no capítulo II, p. 94. BARROS, Francisco Blaudes Souza. Japuara: um relato das entranhas do conflito. Brasília: Ministério do Desenvolvimento Agrário, 2013. Col. Camponeses e o Regime Militar vol. 2. Organização de Marta Cioccari.
}

Comun. \& Inf., Goiânia, GO, v. 18, n. 1, p. 157-173, jan./jun. 2015 
Para se ter uma ideia, os dados mais recentes da Comissão Pastoral da Terra (CPT), divulgados em 2014, indicam a existência, no país, de 874 áreassob litígio.Esses terrenoscorrespondem a pouco mais de seis milhões de hectares e abrigam 99.798 famílias ${ }^{5}$. Em 1.266 conflitos registrados em 2013, mais de 500 mil pessoas estiveram envolvidas e 34 foram assassinadas. Agricultores tradicionais, trabalhadores rurais, posseiros, comunidades quilombolas e indígenasestão na mira dos mais antagônicos interesses. Portanto, para falar sobre o espaço rural, é preciso considerar a tensão (entre pessoas, grupos econômicos, modos de vida e visões de mundo) como uma constante.

De posse dessa premissa, este trabalho se volta ao exercício de compreender como as questões do campo são retratadas pela mídia. Assume, para tanto, uma perspectiva comunicacional, que busca "reler" e "redescrever" o social com base no reconhecimento de uma nova forma de ser organizada por tecnologias autorreferentes, o bios virtual (SODRÉ, 2006; 2013, p. 66 a 73). Considerando que a midiatização acompanha a vida em comum, forma opiniões, engendra sensações e até mesmo captura experiências (SODRÉ, 2006), este artigo enquadra os produtos midiáticos como materializações de uma ordem vigente e, portanto, índices ou "metáforas" (CARVALHO, 2014) de uma realidade fabricada.

O que se pretende discutirneste texto é como as emoções aparecem em duas imagens: uma fotografia do coordenador nacional do Movimento dos Trabalhadores Rurais Sem-Terra (MST), João Pedro Stédile, alterada por computação gráfica (OLIVEIRA, 2013) e exibida na capa da Revista VEJA de 3 de junho de $1998^{6}$; e um desenhoestampado no selo promocional dos Correios, lançado no dia 3 de junho de $2014^{7}$ como parte da campanha do Ano Internacional da Agricultura Familiar (AIAF). São retratos de contextos distintos para o campo que podem, talvez, reunir de forma metafórica os principais debates dos anos 1990 e 2000

O procedimento a ser seguido é o de apresentar, descrever e analisar tais imagens. Permeando esse exercício, e com o propósito de explicar em termos conceituais o que entrelaça o conteúdo aqui tratado, é feita uma delimitação teórica. Primeiramente, aborda-se a relação entre emoções e poder. Em seguida, estabelece-se um debate sobre o uso dos termos "campesinato" e "agricultura familiar". À guisa de conclusão, este texto defendeque as

\footnotetext{
${ }^{5}$ Esse número foi menor que o de 2012 (110.130 famílias), porém maior que a média anual do período entre 1985 e 2006 (671 famílias). A CPT realiza esse trabalho desde 1970 e publica suas pesquisas desde 1985 (CPT, 2013).

${ }^{6}$ Edição no 1459 , de 3 de junho de 1998. Disponível em: <http://veja.abril.com.br/acervo/home.aspx> Último acesso em: 10 jun. 2014

${ }^{7}$ Exatamente 16 anos depois da publicação do "sem-terra raivoso" na capa de VEJA.
}

Comun. \& Inf., Goiânia, GO, v. 18, n. 1, p. 157-173, jan./jun. 2015 
representaçõesdo campo sejam diversas e que, uma vez fazendo-se valer de emoções em suas composições pictóricas, que ampliemo debate do acesso à terra e revelem as contradições sociais que permeiam o campo e a cidade.

\section{COMUNICAÇÃO, EMOÇÕES E PODER}

A noção de representação como sendo a interpretação textual e simbólica que se dá a determinado contexto histórico e espacial é recorrente nos estudos em Comunicação, que desde meados da década de 1960 se dedicam a observar como questões de classe, gênero e raça/etnia são apresentadas e discutidas por produtos de mídia (FREIRE FILHO, HERSCHMANN \& PAIVA, 2004). Por meio da representação é possível reconhecer, portanto, que a mídia traz em si certos entendimentos sociais e produz outros. Da mesma forma, a sociedade guarda os seus julgamentos e valores, mas os reformula na medida em que frui produtos midiáticos. É um processo de disputa e tensão, assim como no caso já dito sobre o campo.

Digamos que um retrato apresenta traços e nuances. Os primeiros, visíveis, dão forma ao desenho; estão carregados de conteúdo social e também de conteúdo midiático sobre o social; dizem textualmente e de forma racional. Já as nuances - não necessariamente explícitas, porém fundamentais para compor a representação - tratam de emoções, afeto e sensorialidade. As emoções, nuance à qual este artigo se atém, podem ser compreendidas como sentimentos histórico e culturalmente construídos (FREIRE FILHO, 2010; BINKLEY, 2010) que, devido a um sistema de crenças, são interpretados de forma valorativa. De acordo com o contexto, as emoções podem soar como positivas ou negativas. Destacadas e/ou camufladas em uma representação midiática, podem servir como "estratégia sensível" (SODRÉ, 2006, p. 16) para orientar o entendimento de indivíduos.

As emoções são vetores de um discurso que está amparado pelo pensamento social e que, portanto, diz respeito a uma estrutura de poder na qual os sujeitos estão inseridos. Nas imagens escolhidas para análise, cujo pano de fundo é o campesinato e a agricultura familiar, do qual tratar-se-á melhor no item 4, há um sentido para se usar a raiva ou a sensação de felicidade. Que sentido é esse? Se já foi ressaltado que o campo é terreno de confrontos e disputas, não é possível considerar que as representações sejam isentas de uma orientação discursiva que, por sua vez, diz respeito a um exercício de poder. O sentido desse poder, produzido e reverberado entre a macro e a microesfera, é o da ordem sociotécnica vigente, da qual a mídia faz parte. 
Conforme Foucault (1982; 1999), a necessidade de a sociedade burguesa capitalista operar seu poder no interior dos sujeitos, formando-os indivíduos e dizendo-lhes sobre o que lhes é mais íntimo, produz subjetividades que tornam-se base para uma "nova economia das relações de poder" (FOUCAULT, 1982, p. 779). O processo de individuação dos sujeitos é forjado como submissão e condição. Assim, determinada orientação normativa, formulada pelas instituições que detém o poder (econômico, político, discursivo), passa a fazer sentido (FOUCAULT, 1982; 1999).

O uso das emoções na mídia serve como um enquadramento e uma nomeação que não foi feita pelos próprios atores sociais, mas sim por produtores profissionais das estruturas de poder. Um sem-terra raivoso ou uma família feliz, como se verá a seguir, têm sua identidade marcada por um poder externo, "pastoral" e coexistente com a vida. Um poder que tange a existência do bios virtual e cuja identidade é atrelada a emoções determinadas socialmente e em diversas outras instituições que não a mídia.

A esse respeito, nos valemos da noção de "governamentalidade" levantada por Sam Binkley (2010) e oriunda dos estudos de poder. Conforme o autor,

a governamentalidade descreve a criação de alinhamentos específicos entre as atividades diárias - mediante as quais os indivíduos procuram mudar a si mesmos, otimizando suas capacidades e transformando aspectos problemáticos - e as estratégias mais amplas, por meio das quais as autoridades governamentais procuram aperfeiçoar os desempenhos econômicos para conter ou minimizar as patologias sociais, e assim por diante (BINKLEY, 2010, p. 90).

Para Binkley, há uma forma de seragenciada pela lógica do neoliberalismo referenciada no "autogoverno", na liberdade plena, na "otimização dos resultados" e na busca pela felicidade. Isso faz com que todo um arsenal científico, calcado na psicologia positiva, produza sujeitos independentes das estruturas sociais e dos aparatos do Estado, plenos com sua condição de competitividade e propensos a agirem sob uma estética específica: a estética da satisfação, do sorriso, da simulação da felicidade e do avesso ao que é dissidente. A "governamentalidade" do neoliberalismo, por exemplo, exige a felicidade e repudia a raiva.

Também empenhado em desmistificar as emoções, João Freire Filho (2010) questiona a formação de um sujeito "cronicamente feliz", que segue um "programa de subjetivação" (FREIRE FILHO, 2010, p. 74) elaborado pela psicologia positiva sob a influência de diversas correntes (da filosofia oriental à autoajuda). A função da "felicidade crônica" é, basicamente, a de fazer com que o indivíduo negue o sofrimento, sendo "resiliente" e agindo conforme o que a macroestrutura político-econômica lhe sugere. 
Conforme o pesquisador, a felicidade não é uma emoção em si mesma, mas sim um conjunto de "sentimentos, ideais e obrigações" (FREIRE FILHO, 2010, p. 77)que se fazem necessários conforme o contexto sociocultural. Isso é o que faz a "governamentalidade" neoliberal mais perigosa, pois exclui grande parte das pessoas que habitam o mundo das contradições.

... não são necessárias grandes amostragens empíricas para concluir que essa peculiar reconfiguração da "procura da felicidade" herdada do iluminismo produz sofrimento em série - para aqueles que não se enxergam à altura da imensidão da tarefa, para aqueles cujas formas de ver o mundo e cujas formas de atuar dentro dele são repelidos ou patologizados simplesmente por distanciarem-se das normas de positividade, por distinguirem-se do jeito de ser das "pessoas cronicamente felizes" (dínamos humanos operando em prol do próprio bem-estar e da ordem socioeconômica). (FREIRE FILHO, 2010, p. 77)

Ao se falar brevemente sobre emoções e poder, volta-se aos produtos de mídia e à representação do campesinato e da agricultura familiar. Como podemos articular esse debate estabelecido nos estudos em Comunicação para a realidade do campo? Estariam as imagens, produzidas em tempos diferentes e em contextos sociais distintos, usando as emoções para produzir sentimentos e sensações que, de alguma forma, indiquem o pensamento da ordem vigente?

\section{AS IMAGENS}

\subsection{O SEM-TERRA RAIVOSO}

Em 1998, a Revista VEJA estampou em uma de suas capas o rosto de João Pedro Stédile, coordenador nacional do Movimento dos Trabalhadores Rurais Sem-Terra (MST), acompanhado da seguinte manchete: "A esquerda com raiva". Na composição, produzida por computação gráfica (OLIVEIRA, 2013), o militante tem a testa franzida, as sobrancelhas levemente arqueadas em diagonal, o olhar fixo e sério, os lábios cerrados. Sobre a sua face, a meia-luz vermelha dá o tom final de uma imagem que muito bem poderia ser associada ao prosaico semblante do demônio (ver figura 1).

Nessa edição, de número $1.459^{8}$, a revista diz “denunciar" as estratégias do MST, cujo objetivo principal seria alterar a ordem socioeconômica vigente. No subtítulo que

\footnotetext{
${ }^{8}$ PETRY, André; OINEGUE, Eduardo. O que eles querem. Os dirigentes do MST dizem que não querem só terra e falam em revolução e socialismo. São Paulo. Revista VEJA. 3 jun. 1998. p. 44 a 48 . Disponível em: $<$ http://veja.abril.com.br/acervo/home.aspx> Último acesso em: 10 jun. 2014.
}

Comun. \& Inf., Goiânia, GO, v. 18, n. 1, p. 157-173, jan./jun. 2015 
acompanha a manchete, VEJA oferece as "pistas" do seu conteúdo: "Inspirados por ideais zapatistas, leninistas, maoístas e cristãos, os líderes do MST pregam a implosão da 'democracia burguesa' e sonham com um Brasil socialista" (p.1). A soma da imagem de Stédile com esses dizeres poderia produzir, em um leitor desavisado, um sentimento de insegurança em relação a algo que ameaça a suposta estabilidade de sua rotina.

Na ocasião, o MST tinha 14 anos de existência e ganhava com frequência as páginas de VEJA. Os rótulos atribuídos ao movimento orbitavam em torno dos termos "arcaico", "fanático", "baderneiro", "satânico" e "terrorista" (SOUZA, 2004). Com a imagem aqui em questão, que já foi analisada e mencionada em outros estudos (SOUZA, 2004; MAGALHÃES \& SOBRINHO, 2010; OLIVEIRA, 2013), a publicação revela seu esforço para deslocar o sentido da organização de milhares de pessoas em torno de um movimento social (que, aliás, é o preferido de VEJA, mas não é o único a representar, na "vida real" e na prática social, os camponeses brasileiros).

No corpo do texto, a reportagem anuncia que o "exército descalço da bandeira vermelha" (p. 44), um tanto "atrasado"9 e confuso em suas reivindicações ${ }^{10}$, está pronto para atacar o patrimônio público e as propriedades privadas. Stédile, personagem da capa, é classificado como "a alma mais radical do MST" (p.44) e, portanto, o pivô capaz de inflar os sem-terra a praticarem "atos violentos". Usando a fala do então ministro da Política Fundiária, Raul Jungmann, a reportagem acusa Stédile de pensar "apenas" em política, sem se preocupar com a inserção dos sem-terra na produção agrícola. "Ele é o produto do ódio que o colonato do Rio Grande do Sul, imigrante e religioso, tem contra a modernidade, a tecnologia e a incerteza do capitalismo"(p. 46).

A frase descontextualizada do ministro é apenas uma alegoria que, articulada à imagem da capa, não somente condena a atuação do MST como a personaliza em uma única figura: João Pedro Stédile. Desta forma, as palavras raiva (contida na capa) e ódio (presente ao longo da reportagem) são estrategicamente utilizadas para despertar no leitor a ideia de que trata-se de uma emoção negativa que pode, até mesmo, abalar a coletividade. $\mathrm{O}$ "desenvolvimento do capitalismo neoliberal" (p. 46), por sua vez, é o objeto desses sentimentos. O capitalismo é o alvo, as pessoas lutam porque não gostam desse alvo e porque

\footnotetext{
9 "Sua principal bandeira, a reforma agrária, é um assunto do século passado, fora de moda, embora ainda insepulto no Brasil dos latifúndios" (p. 42).

10 "Começou pedindo terra em 1984, passou a pedir crédito agrícola dois anos depois, reuniu 40.000 numa marcha a Brasília no ano passado e agora promove invasões e saques porque, no fundo, o MST quer muito mais do que se pensa" (p. 44).
}

Comun. \& Inf., Goiânia, GO, v. 18, n. 1, p. 157-173, jan./jun. 2015

Caderno Casadinho Procad UFG - UFRJ 
são socialistas: esse é o raciocínio de VEJA, que opera por meio de abstrações e dualidades simples. As emoções, assim, são usadas para neutralizar a política e escamotear a importância histórica do campesinato.

Figura 1 - João Pedro Stédile na capa da Revista Veja de 3 jun.

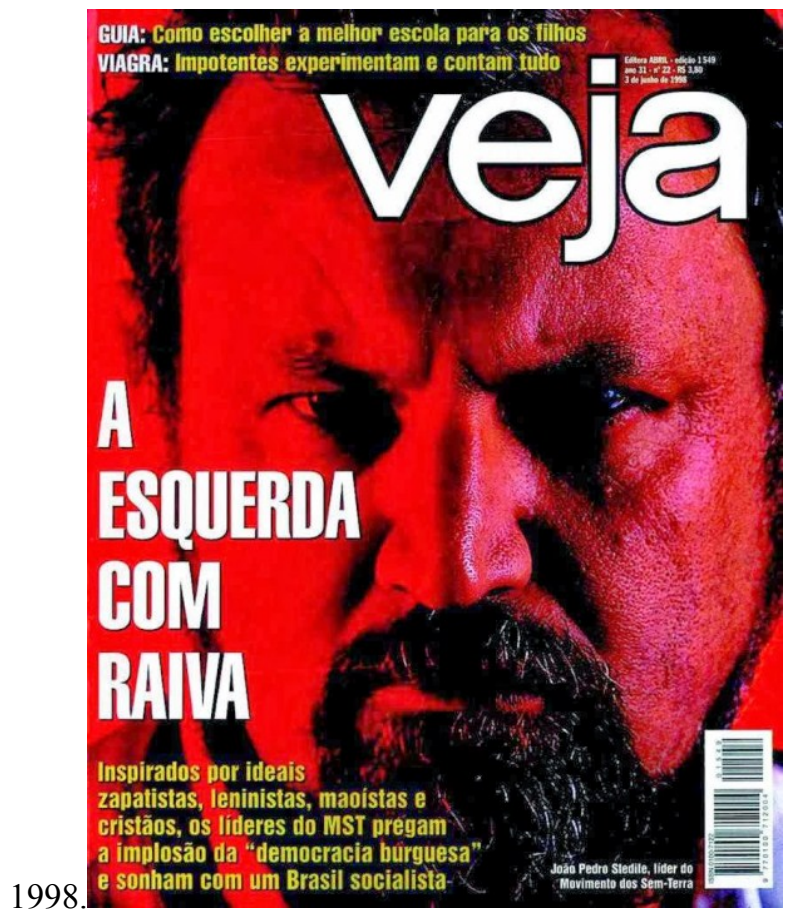

Fonte: Arquivo Veja

\subsection{A FAMÍLIA FELIZ}

Conforme dados das Nações Unidas para Agricultura e Alimentação (FAO) ${ }^{11}, 40 \%$ das residências do planeta têm como principal fonte de renda as atividades derivadas da terra. Isso quer dizer que três bilhões de pessoas sobrevivem de pequenas culturas agrícolas, hortas urbanas, pecuária, pesca e extrativismo. Além disso, produzem um excedente capaz de alimentar aproximadamente $70 \%$ da população mundial. Porém, ainda conforme a FAO, é esse mesmo contingente que padece com a miséria e a fome: $75 \%$ dos casos de subnutrição do globo terrestre foram registrados em áreas rurais da África, da Ásia e da América Latina (FAO, 2014).

Tal contradição, reforçada publicamente por movimentos sociais e entidades não governamentais de todo o mundo, serviu de argumento para que 2014 fosse escolhido pela

\footnotetext{
${ }^{11}$ Apresentados em uma série de relatórios elaborados em parceria com o Banco Mundial (BM) e outras entidades do mundo financeiro. Para este trabalho, nos apoiamos nas informações dispostas no documento Agricultura Familiar - por um sistema alimentar sustentável, disponível em: <http://www.aiaf2014.gov.br/sitemda/sites/site_aiaf/files/argumentos_e_dados_af_no_mundo_-_aiaf_2014.pdfs Acesso em: 05 ago. 2014.
}

Comun. \& Inf., Goiânia, GO, v. 18, n. 1, p. 157-173, jan./jun. 2015 
Assembleia Geral das Nações Unidas (ONU) como o Ano Internacional da Agricultura Familiar (AIAF). De acordo com informações dispostas na página da FAO na Internet ${ }^{12}$, a finalidade seria dar visibilidade às agriculturas locais, consideradas uma "alternativa sustentável" de produção de alimentos para suas regiões e para todo o planeta. Trata-se de um ato simbólico, melhor dizendo, uma ação midiática que tem sido encarada pela sociedade civil como uma resposta ao pujante agronegócio (AGUIRRE, 2014). A expectativa é que, neste ano que finda, o evento tenha alcançado as agendas públicas do mundo de modo a fazê-las reconhecer e debater o tema.

No Brasil, um comitê formado por órgãos governamentais, federações, sindicatos rurais, associações e movimentos sociais formulou um plano de trabalho com diversas frentes, entre elas a difusão de ideias e informações. De 24 "ações de comunicação" listadas no documento do Comitê Brasileiro (AIAF/BRASIL, 2014) ${ }^{13}$, uma em especial chamou a atenção, justamente por sua composição pictórica e pela nuance das emoções: a criação e o desenho de um selo comemorativo, lançado em três de junho de 2014, em parceria com os Correios $^{14}$.

O selo, que circula pelas correspondências do país em série de 900 mil exemplares, foi fabricado em duas partes que, ao serem coladas no papel, formam um desenho naif, inspirando na arte ingênua de artistas autodidatas (ver figura 2). Em sua composição, são exibidos elementos como a horta, a lavoura, o rio, a mata ciliar, o pasto, o trator, o terreiro, a casa simples dos agricultores, os animais (vaca, galinhas e peixes) e, claro, as pessoas. Três homens e três mulheres dividem a força de trabalho e exibem um resultado farto: hortaliças, leguminosas, frutas etc. Uma das mulheres é negra e está em destaque. As cores são vivas, os traços estão em diagonal, as personagens estão sorridentes e o conjunto da obra leva ao entendimento de que o espaço e o tempo da agricultura familiar estão em perfeita harmonia com a natureza. Como se pode observar na imagem, e como se mostrará no item 4, é um retrato semelhante ao que a sociologia clássica idealizou como sendo a sociedade camponesa.

\footnotetext{
${ }^{12}$ Disponível em: < http://www.fao.org/family-farming-2014/pt/> Acesso em: 7 de março de 2014.

13 Conforme o plano de trabalho do Comitê Brasileiro, que pode ser acessado a partir deste link: < http://www.aiaf2014.gov.br/sitemda/sites/site_aiaf/files/plano_de trabalho_comite_brasileiro_aiaf_2014_versao final.pdf> Acesso em: 07 ago. 2014.

$\overline{14}$ De acordo com notícia publicada no site do Comitê Brasileiro do AIAF. Disponível em: $<$ http://www.aiaf2014.gov.br/sitemda/noticias/agricultura-familiar-ganha-selo-comemorativo-dos-correios>

Acesso em: 6 jun. 2014.
}

Comun. \& Inf., Goiânia, GO, v. 18, n. 1, p. 157-173, jan./jun. 2015 
Figura2 -selo comemorativo do Ano Internacional da Agricultura Familiar.

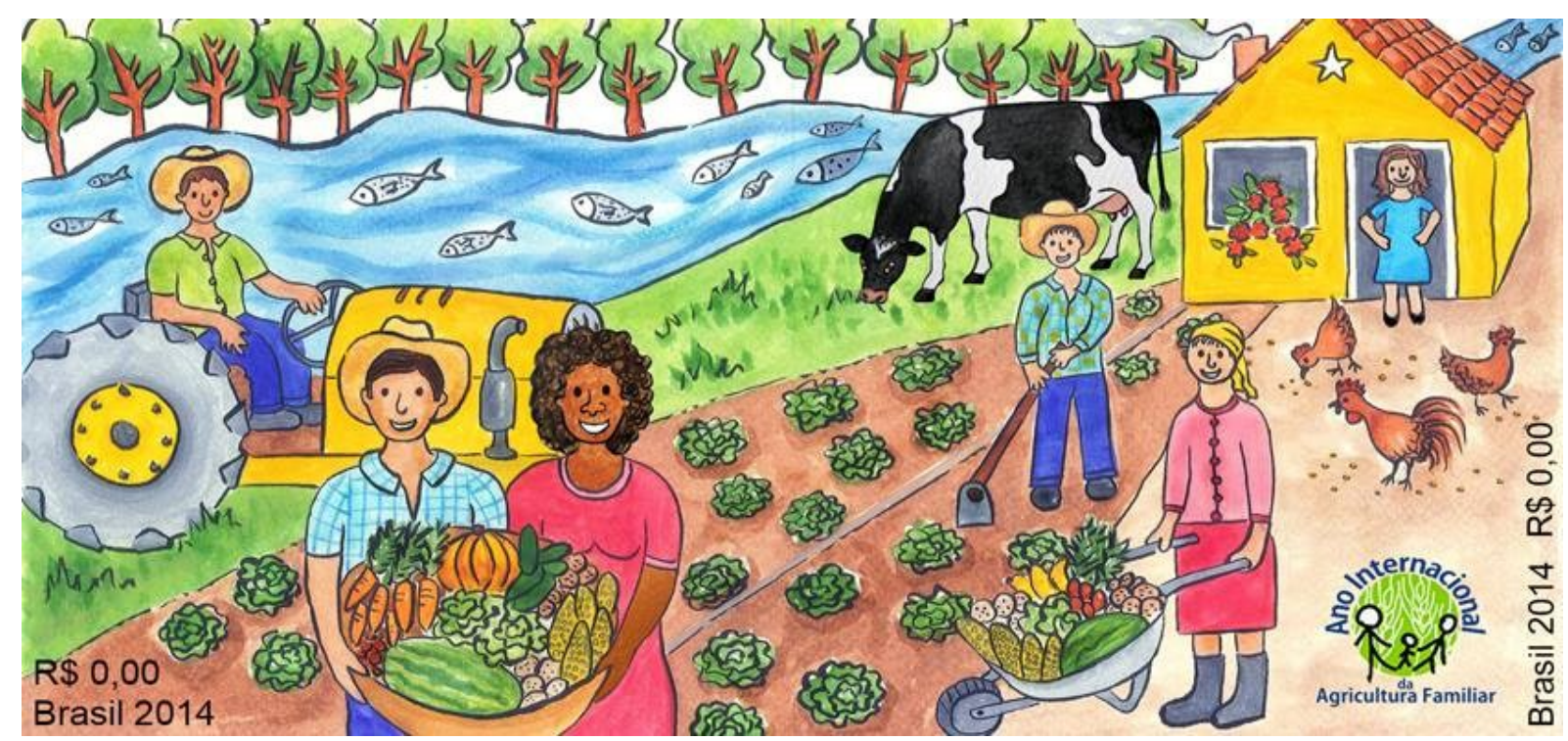

Fonte: AIAF/Brasil.

Este selo é comercializado ao mesmo tempo em que a noção de agricultura familiar é legitimada e popularizada no contexto brasileiro. Uma rápida passagem pelo buscador de conteúdos Google.com, por exemplo, capta 738.000 resultados associados à expressão no prazo de 0,34 segundos ${ }^{15}$. Em repositórios especializados, tais como Domínio Público, Banco de Teses e Portal de Periódicos da Coordenação de Aperfeiçoamento de Pessoal de Nível Superior (Capes) ${ }^{16}$, os números também são relevantes: 655 dissertações e teses registradas entre 2008 e 2012, das mais diversas áreas ${ }^{17}$, além de 3.011 artigos publicados em revistas especializadas nacionais e internacionais. Com a campanha do AIAF no Brasil, é possível que a popularidade do termo aumente ainda mais e que este difuso grupo formado por diversos atores sociais do campo (conforme se verá adiante) passe a existir não somente para ações de políticas públicas, mas também no imaginário social e no rol de influências do mercado.

Deste modo, a dúvida que fica é: se o AIAF é uma campanha para trazer à tona questionamentos referentes às crises no campo, provocadas por um modelo agroexportador e

\footnotetext{
${ }^{15}$ Disponível em: <www.google.com>. Palavra-chave: agricultura familiar. Último acesso em 3 jul. 2014. Vale destacar que, em uma primeira busca feita no dia 11 de março de 2014, o resultado foi: 831.000 em 0,25 segundos.

16 Disponíveis, respectivamente, em: <www.dominiopublico.gov.br>, <www.bancodeteses.capes.gov.br > e <www.periodicos.capes.gov.br> Acesso em: 08 de março de 2014.

${ }^{17}$ Os trabalhos são vinculados a Programas de Pós-Graduação em Ciências Biológicas, Ciências Ambientais, Ciências Veterinárias, Gestão Ambiental, Agronomia, Agronegócio, Administração, Economia, Sociologia, Antropologia, Turismo, Educação, entre outros.
}

Comun. \& Inf., Goiânia, GO, v. 18, n. 1, p. 157-173, jan./jun. 2015 
monocultor, à miséria, à dificuldade de produção de pequenos agricultores etc., por que este retrato em forma de selo promocional pinta a agricultura familiar nas bases da felicidade? Qual o interesse em retratar a realidade dos agricultores familiares de forma alegre e positiva? Por que as contradições, mais uma vez, não são nem traço e nem nuance da representação midiática?

\section{CAMPESINATO E AGRICULTURA FAMILIAR}

A sociedade camponesa é compreendida pela Sociologia clássica como uma forma de vida derivada do período feudal e relativamente autônoma à sociedade global. Sua população, sua economia e sua cultura estariam centradas no grupo doméstico e este, por sua vez, estaria voltado ao próprio desenvolvimento. As relações de proximidade entre os atores sociais garantiriam uma divisão de tarefas entre os membros do grupo. O cultivo da terra, por sua vez, asseguraria uma produção diversificada e voltada para a subsistência (MENDRAS, 1976; WANDERLEY, 1996). Essa classificação, ancorada na dualidade comunidade/sociedade, orientou uma série de debates a respeito da sobrevivência de modelos societários pré-capitalistas no mundo capitalista, urbanizado e industrializado.

Vale mencionar o raciocínio do francês Henri Mendras (1976), que levantou a tese do "fim do camponês"18. Para ele, o campesinato apresentava um modo de produzir correspondente ao próprio modo de sobreviver, alimentado pelo vínculo familiar, pela conservação da natureza e pela constituição de uma sabedoria milenar e ritualística. Ao entrar em contato com uma política desenvolvimentista que instaurou no campo a lógica da individualização (da produção, do trabalho e do convívio), essa sociedade, para o autor, teria perdido suas características e sucumbido. O campo se tornou, assim, um ambiente "artificial" a ponto de imbricar-se às zonas urbanas. O camponês, por sua vez, teria se convertido em "produtor rural", "trabalhador-operário" ou "dirigente agrícola", perdendo sua tradição. "Em uma geração a França viu desaparecer uma civilização milenar, constitutiva dela mesma" 19 (MENDRAS, 1976, p. 317)

No Brasil, Antônio Cândido operou com uma chave interpretativa semelhante, ao se debruçar sobre o caipira do interior de São Paulo. Disposto a refutar os rótulos de "preguiça",

\footnotetext{
${ }^{18} \mathrm{O}$ estudo de Mendras tem como referências o Estado do Bem-Estar Social francês, que no pós-guerra desenvolveu políticas voltadas a um processo de mecanização e divisão da produção agrícola, orientando-a a um mercado global e incentivando uma especialização do trabalho no campo (MENDRAS, 1976).

19 Tradução livre para o trecho: "em une génération la France a vu disparaître une civilisation millénaire, constitutive d'elle-même" (MENDRAS, 1976, p. 317).
}

Comun. \& Inf., Goiânia, GO, v. 18, n. 1, p. 157-173, jan./jun. 2015 
"indolência" e "ignorância" atribuídos aos pequenos sitiantes, o autor descreveu a existência de uma cultura "rústica", com sabedoria única e dificuldades de adaptação ao trabalho exaustivo então imposto pelos barões do café. Cândido também destacou o fato de muitos camponeses, depois de perderem suas terras para os latifundiários locais, serem obrigados ao deslocamento territorial.

A posse, ou ocupação de fato da terra, pesou na definição da sua vida social e cultural, compelindo-o, frequentemente, ao status de agregado, ou empurrando-o para as áreas despovoadas do sertão, onde o esperava o risco da destruição física ou da anomia social (CÂNDIDO, 1972, p. 56).

A distribuição de terras no Brasil, que a partir de 1850 passou a ser realizada com base em relações de compra e venda, é para Maria de Nazareth Wanderley (1996) e Ariovaldo Umbelino de Oliveira (2001) um traço marcante do que se pode chamar de campesinato brasileiro. É a luta pela sobrevivência no lugar de origem que confronta a concentração fundiária e dá um caráter político para a figura do camponês. Nas décadas de 1940 e 1950 , com a organização dos trabalhadores rurais em entidades classistas, o termo campesinato ganhou o lugar da prática social e passou a ser pensado a partir da capacidade de se construir a história. Influenciados pelo debate da "revolução brasileira", os movimentos sociais transformaram a revolta em valor e passaram a questionar o que a Sociologia encarava como passividade do camponês (OLIVEIRA, 2001; MEDEIROS, 2009).

O termo "agricultura familiar" acompanhou todo esse debate do campesinato ao longo do século XX, mas surgiu com força no Brasil a partir da década de 1980, quando sindicatos rurais ${ }^{20}$ se uniram a movimentos sociais recém-criados ${ }^{21}$, ampliaram sua pauta de reivindicação (para além da regularização trabalhista) e passaram a cobrar a inclusão dos produtores rurais em políticas específicas de acesso a terra, de assistência técnica e de financiamento da produção. A expressão "agricultor familiar", nesse contexto, tornou-se sinônimo de um grupo difuso e até então invisível, formado por proprietários de pequenas áreas, assentados, arrendatários, colonos, trabalhadores rurais etc., gente que foi alijada do campo ao longo dos processos de "modernização" e "especialização" da agricultura (ALTAFIN, 2007). Deste modo, "agricultor familiar" vem para, aos poucos, substituir o termo camponês.

\footnotetext{
${ }^{20}$ Tais como a Confederação Nacional dos Trabalhadores na Agricultura (Contag).

${ }^{21}$ A exemplo do MST, neste trabalho já mencionado, do Movimento dos Pequenos Agricultores (MPA) e do Movimento dos Atingidos por Barragens (MAB).
}

Comun. \& Inf., Goiânia, GO, v. 18, n. 1, p. 157-173, jan./jun. 2015 
Em resposta à pressão social, o Estado criou o Programa Nacional de Fortalecimento da Agricultura Familiar (Pronaf), em 1996, e o Ministério do Desenvolvimento Agrário (MDA), em 1999. Em 2000, o Instituto de Colonização e Reforma Agrária (INCRA), em cooperação técnica com a FAO, publicou um primeiro diagnóstico sobre os agricultores familiares no país, denunciando a falta de diferenciação entre esse grupo e os agricultores patronais nas ações do Estado (INCRA/FAO, 2000).

Em 2006, foi aprovada a Lei $\mathrm{n}^{\mathrm{o}} 11.326$, formulada para orientar ações de políticas públicas voltadas ao campo ${ }^{22}$. No mesmo ano, o Instituto Brasileiro de Geografia e Estatística usou, pela primeira vez, no seu Censo Agropecuário, uma metodologia que identificasse a produção e o modo de vida dos agricultores familiares. As pesquisas identificaram 12,3 milhões de pessoas habitando e/ou trabalhando em cerca de 4,3 milhões de "estabelecimentos rurais familiares" (CENSO, 2006) ${ }^{23}$.Com área total de 80,10 milhões de hectares, esses estabelecimentos corresponderiama $24 \%$ do território nacional, empregariam três vezes mais do que a agricultura convencional e produziriam 70\% dos alimentos consumidos no país entre grãos, leguminosas, tubérculos, frutas, hortaliças, carnes e leite ${ }^{24}$. Tais informações foram deveras usadas pelo Estado. O MDA multiplicou suas ações de políticas públicas, criou novos editais de fomento, aumentou o valor dos financiamentos e deu partida a umasérie de ações midiáticas para estimular a inserção dos agricultores familiares no mercado.

$\mathrm{Na}$ academia, os estudiosos brasileiros se debruçaram sobre esse cenário e se dividiram em duas correntes: i) a que enxerga no agricultor familiar um ator social criado pelo Estado, a partir de políticas públicas, inserido nos processos capitalistas e, portanto, diferente do antigo camponês; ii) a que enxerga no agricultor familiar, a despeito do tardio

\footnotetext{
${ }^{22}$ Conforme estabelece esse dispositivo, fazem parte da agricultura familiar pessoas que residem em áreas rurais, são proprietárias de um terreno com extensão máxima de quatro módulos fiscais (o equivalente, em média, a 18 hectares) e realizam seus empreendimentos de modo que a administração, a manutenção e boa parte da mão-deobra empregada sejam de responsabilidade dos membros da própria família. Nesse bojo, são reconhecidos como "agricultores familiares" tanto os chamados "pequenos proprietários", "pequenos produtores rurais" ou "agricultores tradicionais" como "colonos, posseiros, assentados da reforma agrária, trabalhadores sem-terra, pescadores, silvicultores, aquicultores, extrativistas, comunidades indígenas e quilombolas". Disponível em: $<$ http://www.planalto.gov.br/ccivil_03/_ato2004-2006/2006/lei/111326.htm> Acesso em 05 de dezembro de 2013.

${ }^{23}$ É bom abrir um parêntese e destacar que 3,2 milhões desses estabelecimentos são proprietários de suas terras e as adquiriram por meio de compra ou herança. Do restante, 170 mil são "assentado sem titulação definitiva", 691 mil possuem acesso temporário ou precário às terras, tornando-se arrendatários (196 mil), parceiros (126 mil) ou ocupantes (368 mil). Além disso, ainda há 255 mil agricultores familiares sem qualquer natureza de área para produzir (CENSO, 2006).

${ }^{24}$ Em 2006, conforme o Censo Agropecuário, a agricultura familiar foi responsável por " $83 \%$ da produção nacional de mandioca, $69,6 \%$ da produção de feijão, $45,5 \%$ do milho, $38 \%$ do café, $33 \%$ do arroz, $58 \%$ do leite, possuíam $59 \%$ do plantel de suínos, $51 \%$ do plantel de aves, $30 \%$ dos bovinos, e produziram $21 \%$ do trigo. A cultura com menor participação da agricultura familiar foi a soja (14\%), um dos principais produtos da pauta de exportação brasileira" (CENSO, 2006b).
}

Comun. \& Inf., Goiânia, GO, v. 18, n. 1, p. 157-173, jan./jun. 2015 
reconhecimento do Estado, um ator social com raízes históricas. A nosso ver, por tudo o que narramos até aqui, a segunda opção é mais interessante por considerar o camponês como uma personagem atual, deste mundo, e não apenas um mito da era pré-moderna ou pré-capitalista.

(...) a história dos produtores de alimentos no Brasil está ligada à diferente trajetória desses cinco grupos: índios, negros, mestiços, brancos não herdeiros e imigrantes europeus. Apesar de diferentes, estão ligados sob uma mesma unidade: a posição secundária que ocupavam dentro do modelo de desenvolvimento do país desde sua origem. Enquanto a grande propriedade voltada à monocultura de exportação recebia estímulos e garantias dos governantes, esse mosaico de formas camponesas ligadas a cultivos alimentares dirigidos ao abastecimento interno era colocado à margem das políticas públicas (ALTAFIN, 2007, p. 9)

Mas é preciso ressaltar a importância de se observar as "rupturas" e "continuidades" entre o camponês e o agricultor familiar, enquanto atores sociais carregados de memória (WANDERLEY, 2003). Tais fragmentações dizem respeito não somente ao trabalho, ao consumo e à transmissão de saberes tradicionais - o que Mendras (1976) argumentava - mas também ao interior da vida familiar.

Em linhas gerais, é possível afirmar que o camponês e o agricultor familiar derivam de uma mesma situação de exclusão no campo, mas podem vir a se tornar atores sociais distintos, conforme o contexto em que são inseridos: oravinculados ao Estado e beneficiados pelas políticas para o setor agrícola ora convertidos em "pauta" da sociedade civil; ora situados completamente à margem da sociedade ora acolhidos por movimentos sociais. E se a política econômica brasileira passa a oscilar entre o neoliberalismo e o desenvolvimentismo (MARICATO, 2011), vale diferenciar ambos os termos, sem dissociá-los. A agricultura familiar é tida como uma "alternativa" aos efeitos socialmente avassaladores do agronegócio, mas na prática também pode ser vista como uma possibilidade de integração dos produtores rurais ao mesmo agronegócio. Assim sendo, para que as lutas sociais de outrora e correntes não sejam esquecidas, é preciso manter abertura aos questionamentos.

\section{CONSIDERAÇÕES FINAIS}

Não é possível falar sobre o campo, ou sobre a representação que se faz dele, sem pensar no ódio e na raiva como emoções fundamentais, socialmente construídas e alimentadas por profundas e históricas contradições. No entanto, o que vemos comumente nos produtos de mídia, como parte da reprodução do pensamento social, é outra coisa. A raiva sobressalente na luta pela terra, aparentemente, não tem razão de existir e é reproduzida como uma emoção valorativa pré-determinada. A raiva é negativa e, por isso, atribuída aos sem-terra. De acordo 
com a imagem do sem-terra raivoso que aqui foi estudada, não há razões históricas para a luta pela terra, há apenas um sentimento irracional e sem explicação. Isso é o que se quer transmitir quando a representação é referente ao campesinato.

Já a satisfação plena vem marcar o "novo" tempo da agricultura familiar, temporariamente tutelada pelo Estado desenvolvimentista no qual estamos inseridos. Se a raiva é oca, dúbia e, no máximo, representa o delírio de socialistas e fanáticos, a felicidade implicaem superação. É conquistada na medida em que os produtores rurais se integram ao agronegócio exportador e conciliam sua situação, justamente, com a ordem vigente questionada pelo campesinato e pela própria campanha do AIAF. A felicidade neutraliza as tensões que o campo ainda vive, seja no interior da família seja em relação às políticas agrícolas adotadas no país.

Ao apresentar essas duas imagens, o objetivo deste texto foi mostrar que, tanto de parte da revista VEJA como de parte da campanha publicitária do MDA e da FAO, as emoções têm sido usadas para camuflar as tensões vivenciadas no campo. Assim, tornam-se parte de um jogo para evitar questionamentos de base, tais como: a necessidade de uma reforma agrária ainda não feita no país; as origens violentas, patriarcais e desiguais da família; a situação de expropriação e miséria ainda não superada por milhares de pessoas.

Seria possível uma representação midiática do campesinato que usasse as emoções para instigar esse debate e não para extingui-lo da memória coletiva? É possível pintar esse quadro com nuances que não sugiram uma forma de ser e de governança organizada pela ordem sociotécnica vigente de faceta neoliberal?

\section{REFERÊNCIAS}

ANO INTERNACIONAL DA AGRICULTURA FAMILIAR/ COMITÊ BRASIL. Plano de trabalho. 2014. Disponível em: $<\mathrm{http} / /$ www.aiaf2014.gov.br/sitemda/sites/site aiaf/files/plano de trabalho comite brasileiro aiaf 2 014_versao_final.pdf> Acesso em: 2 ago. 2014.

AGUIRRE, C. Q. Ano Internacional da Agricultura Familiar 2014: uma corrida de longa distância. Revista Mundos Rurales, La Paz, Bolívia, n. 10, jul. 2014. Disponível em: $<$ http://issuu.com/aspta/docs/mr-10_cipca $>$. Acesso em: 25 ago. 2014.

ALTAFIN, I. Reflexões sobre o conceito de agricultura familiar. Brasília: CDS/UnB, 2007.

BARROS, F. B. S. Japuara: um relato das entranhas do conflito.Brasília: Ministério do Desenvolvimento Agrário, 2013. (Coleção Camponeses e o Regime Militar, 2). 
BINKLEY, S. A felicidade e o programa de governamentabilidade neoliberal. In: FREIRE FILHO, João (Org.). Ser feliz hoje: reflexões sobre o imperativo da felicidade. Rio de Janeiro: FGV, 2010.

CÂNDIDO, A. O caipira e sua cultura. In: FERNANDES, Florestan (Org.). Comunidade e

Sociedade no Brasil: leituras básicas de introdução ao estudo macro-sociológico do Brasil. São Paulo: Ed. Nacional; EDUSP, 1972.

CARVALHO, C. A.de. A comunicação como metáfora para a compreensão do social. In: Encontro Anual da Associação Nacional dos Programas de Pós-Graduação em Comunicação (Compós), 23., 2014, Pará. Anais...Pará: Universidade Feral do Pará, 2014. Disponível em: <www.compos.org.br> Acesso em 10 ago. 2014.

INSTITUTO BRASILEIRO DE GEOGRAFIA E ESTATÍSTICA (IBGE). Censo Agropecuário 2006. Disponível em:<http://www.ibge.gov.br/home/estatistica/economia/agropecuaria/censoagro/> . Acesso em: 05 dez. 2013.

INSTITUTO BRASILEIRO DE GEOGRAFIA E ESTATÍSTICA (IBGE). Censo Agropecuário 2006.Agricultura Familiar - Brasil, Grandes Regiões e Unidades da Federação. Disponível em: $<\mathrm{http} / /$ www.ibge.gov.br/home/estatistica/economia/agropecuaria/censoagro/agri_familiar_2006_2/def ault.shtm> Acesso em: 05 dez. 2013.

CUNHA, E. da. Os sertões: Campanha de Canudos. 20. ed. Rio de Janeiro: Ediouro, 1998.

IANNI, O. Origens agrárias do Estado brasileiro. São Paulo: Brasiliense, 2004.

INSTITUTO DE COLONIZAÇÃO E REFORMA AGRÁRIA (INCRA); ORGANIZAÇÃO DAS NAÇÕES UNIDAS PARA AGRICULTURA E ALIMENTAÇÃO (FAO). Novo retrato da agricultura familiar: o Brasil redescoberto. Relatório de Cooperação Técnica, Brasília, 2000. Disponível em: $<$ http://uenf.br/Uenf/Downloads/AGRONOMIA_1271_1095426409.pdf> Acesso em: 10 jan. 2014.

FREIRE FILHO, J. A felicidade na era de sua reprodutibilidade científica: construindo "pessoas cronicamente felizes". In: FREIRE FILHO, João (Org.). Ser feliz hoje: reflexões sobre o imperativo da felicidade. Rio de Janeiro: FGV, 2010.

FREIRE FILHO, J.; HERSCHMANN, M.; PAIVA, R. Rio de Janeiro: estereótipos e representações midiáticas. E-COMPÓS,v. 1, 2004. Disponível em: $<$ http://www.compos.org.br/e-compos $>$ Acesso em: 08 jul. 2014.

FOUCAULT, M. The subject and power. Critical Inquiry, Chicago, v. 8, n. 4, p. 777-795, 1982.

FOUCAULT, M. História da sexualidade I: a vontade de saber. 13. ed. Rio de Janeiro: Edições Graal, 1999.

MAGALHÃES, B.; SILVA SOBRINHO, H. F. da. O efeito ideológico de deslocamento no discurso da imprensa sobre o MST: de pobres da terra a baderneiros. Veredas Online, Juiz de Fora, v. 2, p.37$50,2010$.

MARICATO, E. A cidade sustentável. In: Congresso Nacional de Sindicatos de Engenheiros CONSENGE, 9., 2011, [S.1.]. Anais... [S.1., s.n.], 2011. p 9-99 Disponível em: < http://www.adital.com.br/arquivos/2012/02/pt\%20a\%20cidade\%20sustent $\% \mathrm{C} 3 \% \mathrm{~A} 1$ vel $\% 20$ $\% 20$ erminia\%20maricato.pdf $>$ Acesso em 12 set. 2014.

MARTINS, J. S. O cativeiro da terra. 9. ed.. São Paulo: Contexto, 2013.

Comun. \& Inf., Goiânia, GO, v. 18, n. 1, p. 157-173, jan./jun. 2015

Caderno Casadinho Procad UFG - UFRJ 
MEDEIROS, L.S. Apresentação. In: FACÓ, R. Cangaceiros e fanáticos: gênese e lutas. Rio de Janeiro: UFRJ, 2009.

MENDRAS, H. La fin des paysans (Conclusion et Postface). Paris: Colin, 1976.

NAÇÕES UNIDAS PARA AGRICULTURA E ALIMENTAÇÃO (FAO). Agricultura Familiar: por um sistema alimentar sustentável. 2014. Disponível em: $<$ http://www.aiaf2014.gov.br/sitemda/sites/site_aiaf/files/argumentos_e_dados_af_no_mundo_aiaf_2014.pdf> Acesso em: 05 ago. 2014.

OLIVEIRA, A. D. A imagem de João Pedro Stédile, líder do MST, na capa da Revista Veja. Encontro Nacional de Estudos da Imagem e I Encontro Internacional de Estudos da Imagem. 4., 2013, Londrina. Anais... Londrina: UEL, 2013. Disponível em:

$<$ http://www.uel.br/eventos/eneimagem/2013/anais2013/trabalhos/pdf/Airton\%20Donizete\%20de\%20 Oliveira.pdf $>$. Acesso em: 08 jul. 2014.

OLIVEIRA, A. U. de. A longa marcha do campesinato brasileiro: movimentos sociais, conflitos e Reforma Agrária. Estudos Avançados, v.15, n.43, p. 185-206, 2001.

PETRY, A; OINEGUE, E. O que eles querem. Os dirigentes do MST dizem que não querem só terra e falam em revolução e socialismo. VEJA. São Paulo: Abril. 3 jun. p. 44-48, 1998. Disponível em: $<$ http://veja.abril.com.br/acervo/home.aspx> Acesso em: 10 jun. 2014.

SODRÉ, M. As estratégias sensíveis: afeto, mídia e política. Petrópolis: Vozes, 2006.

SODRÉ, M. Um novo sistema de inteligibilidade. Questões Transversais: Revista de Epistemologias da Comunicação, São Leopoldo, v. 1. n. 1, p. 66-73. 2013.

SOUZA, E. F.Do silêncio à satanização: o discurso de Veja e o MST. São Paulo: Annablume, 2004.

WANDERLEY, M. de N. B. Agricultura familiar e campesinato: rupturas e continuidade. Estudos Sociedade e Agricultura, Rio de Janeiro, CPDA/UFRRJ, n. 21, p. 42-61, 2003.

WANDERLEY, M. de N. B. Raízes históricas do campesinato brasileiro. Encontro Anual da ANPOCS. 20., 1996. Caxambu (MG) Anais... Caxambu (MG), 1996. Disponível em: $<$ http://www.reformaagrariaemdados.org.br>. Acesso em: 04 mai. 2014. 